\title{
The first confirmed finding of Leptosporomyces mundus (Basidiomycota) in Russia
}

\author{
Yuliia R. Khimich ${ }^{1} \&$ Ivan V. Zmitrovich ${ }^{2}$ \\ ${ }^{1}$ Laboratory of Terrestrial Ecosystems, Institute of the Industrial Ecology Problems of the North of the Kola Science \\ Center, Russian Academy of Sciences, Academic Campus, 14a, Apatity, Murmansk Region, 184209, Russia. \\ E-mail: ukhim@inbox.ru \\ ${ }^{2}$ Laboratory of Systematics and Geography of Fungi, Komarov Botanical Institute, Russian Academy of Sciences, Prof. \\ Popov str., 2, 197376, St. Petersburg, Russia. E-mail: IZmitrovich@binran.ru
}

\begin{abstract}
The first record of Leptosporomyces mundus in Russia is reported. The short note on distribution of this species in East Europe as well as main diagnostic features are presented. An detailed description of Russian material on the species is given and additional Transcarpatian (Ukraine) material is cited. It is supposed that the earlier record of L. mundus from Russia in literature is referred to the Ukrainian material of Parmasto.
\end{abstract}

Key words: Leptosporomyces mundus; rare species; morphology; distribution; Murmansk Region

\section{INTRODUCTION}

The genus Leptosporomyces (Atheliaceae, Atheliales) is represented in Russia by eight species - L. fuscostratus (Burt) Hjortstam, L. fusoideus (Jülich) Krieglst., L. galzinii (Bourdot) Jülich, L. montanus (Jülich) Ginns \& M.N.L. Lefebvre, L. mutabilis (Bres.) Krieglst., L. raunkiaeri (M.P. Christ.) Jülich, L. roseus Jülich, L. septentrionalis (J. Erikss.) Krieglst. (Zmitrovich, 2008). In cited monograph $L$. mundus was mentioned as a provisional species. However, there appeared information about the finding of this species in Russia without data on distribution and ecology (Bernicchia \& Gorjón, 2010). This finding was referred later on (Kunttu et al., 2016), but it is still unclear, on what data was based this record.

A recent floristic investigation in northwestern part of the Murmansk Region, especially in Pasvik State Nature Reserve, brought a number of new regional records. Among them, there are some rare species e.g., Paullicorticium ansatum Liberta, Postia parva (Renvall) Renvall. The study of mycobiota in the Pasvik Reserve was started in 2008. Preliminary list of aphyllophoroid fungi has included 124 species (Khimich et al., 2015). In the present paper, the first confirmed record of Leptosporomyces mundus in Russia is discussed here.

\section{MATERIAL AND METHODS}

The Pasvik State Nature Reserve is situated in the north-western part of Murmansk Region (the north-west of Russia) and lies as a narrow belt on the east bank of the Pasvik River, along the Russian-Norwegian border. Reserve is situated in the Northern boreal zone according to Ahti et al. (1968). Pine (Pinus sylvestris L.) forests dominate and occupy about $90 \%$ of the forested area and are at the northern limit of distribution. Spruce (Picea obovata Ledeb.) is very rare in the reserve, but there are several stands of up to 20 spruce trees. Birch (Betula pubescens Ehrh.) forests are frequent and are confined to the banks of rivers, streams and to former agricultural lands. Aspen (Populus tremula L.) often grows as an admixture in pine and birch forests on fertile soils (Moshnikov \& Krutov, 2010). General survey of the climate, soil and vegetation of the Pasvik Reserve was presented by Borovichev and Boychuk (2016).

7 days-long field work was carried out by the first author in August 2015, mainly in previously understudied areas in the Pasvik Reserve. Wood logs were chosen by random route method and aphyllophoroid fungi occurred were collected.

Samples were studied under the LOMO light microscope. Microscopic features were observed in 3\% KOH solution, Melzer's reagent (IKI). Ten spores per specimen were measured. The following abbreviations are used: $\mathrm{L}=$ mean spore length, $\mathrm{W}=$ mean spore width. The additional Transcarpatian herbarium specimen of Leptosporomyces mundus from LE was studied. 
The specimens are kept in the herbarium INEP - herbarium of the Institute of the Industrial Ecology Problems of the North KSC.

\section{RESULTS AND DISCUSSION}

Only single specimen of the Leptosporomyces mundus in question from the former USSR was found by us within Parmasto's exsiccates - namely No 121 from the series "Corticiaceae URSS II", collected by Parmasto in Transcarpatia (Ukraine) in 1956 . This finding was accounted in the "Conspectus systematis Corticiacearum" (Parmasto, 1968) and, it is possible, in such status Leptosporomyces mundus was considered as distributed within Russia by consequent European authors.

The following description presents the first finding of Leptosporomyces mundus from Russian territory (in modern administrative sense).

LEPTOSPOROMYCES MUNDUS (H.S. Jacks. \& Dearden) Jülich (Figs. 1, 2)

Fruit bodies resupinate, annual, athelioid, fragile and easily separable from the substrate, $0.3-2 \mathrm{~cm}$ long, partly merging, thin, margin is unclear, white, cobwebby. Hymenophoral surface as fine pellicular layer, smooth, later cracked, white to cream or with a fine orangebrown hue. Hyphal system monomitic, hyphae clamped, 1.6-2.8 $\mu \mathrm{m}$ in diameter, incrustation absent to unclear, thin-walled or with thickened walls near a substrate. Leptocystidia basally clamped, thin-walled, hyphoid, cylindrical of fusoid, often slightly sinuous, tapering towards the apex, 23-35 × 3-3.5(4) $\mu \mathrm{m}$. Basidia subcylindrical to subclavate, thin-walled, basally clamped, $8-16(-18) \times 3-4 \mu \mathrm{m}$, with four sterigmata up to $3 \mu \mathrm{m}$ long. Basidiopores ovoid or ellipsoid, ventrally flattened and in some projections shortcylindraceous, thin-walled, 3-4(-4.5) $\times 1.7-2$ $\mu \mathrm{m}, \mathrm{L}=3.2 \mu \mathrm{m}, \mathrm{W}=1.8 \mu \mathrm{m}, \mathrm{Q}=1.5-2.2$, with a prominent apiculus, IKI-.

Specimen studied: Russia, Murmansk Region, Pasvik State Nature Reserve, north-west bank of the Kaskamajarvi Lake, 69.287091 ${ }^{\circ} \mathrm{N}, 29.453580^{\circ} \mathrm{E}$, on fallen trunk of Pinus sylvestris in pine forest, $22 \mathrm{Au}-$ gust 2015, coll. Y. R. Khimich, det. Y. R. Khimich and I.V. Zmitrovich (INEP 1638).

Additional material examined: Ukraine, Bogdan Region, on fallen log of $P$. abies in a mixed forest, 19 August 1956, coll. and det. E. Parmasto (LE 168615, “Corticiaceae URSS II", N 121).

Leptosporomyces mundus is easily recognizable by its projecting leptocystidia. Few species belonging to the genus Athelia have similar cystidia (A. cystidiolophora Parmasto, A. phialophora Zmitr. \& Spirin, A. malyshevae Zmitr.), but their basidiospores have different size, besides, $L$. mundus has regular clamps on hyphae.

The distribution of L. mundus in Europe, to the best of our knowledge, is limited to Austria,

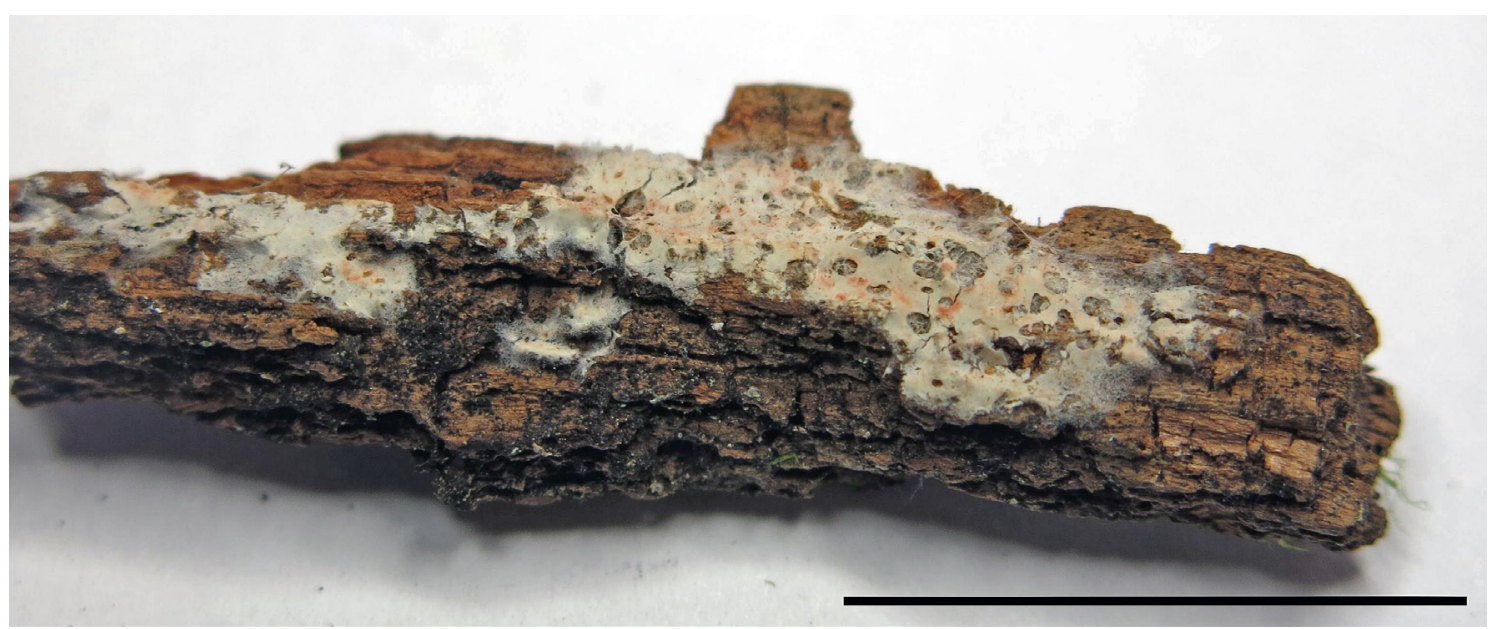

Fig. 1. Leptosporomyces mundus on fallen trunk of Pinus sylvestris (INEP 1638). Photo by Yuliia Khimich. Scale bar $=2 \mathrm{~cm}$. 


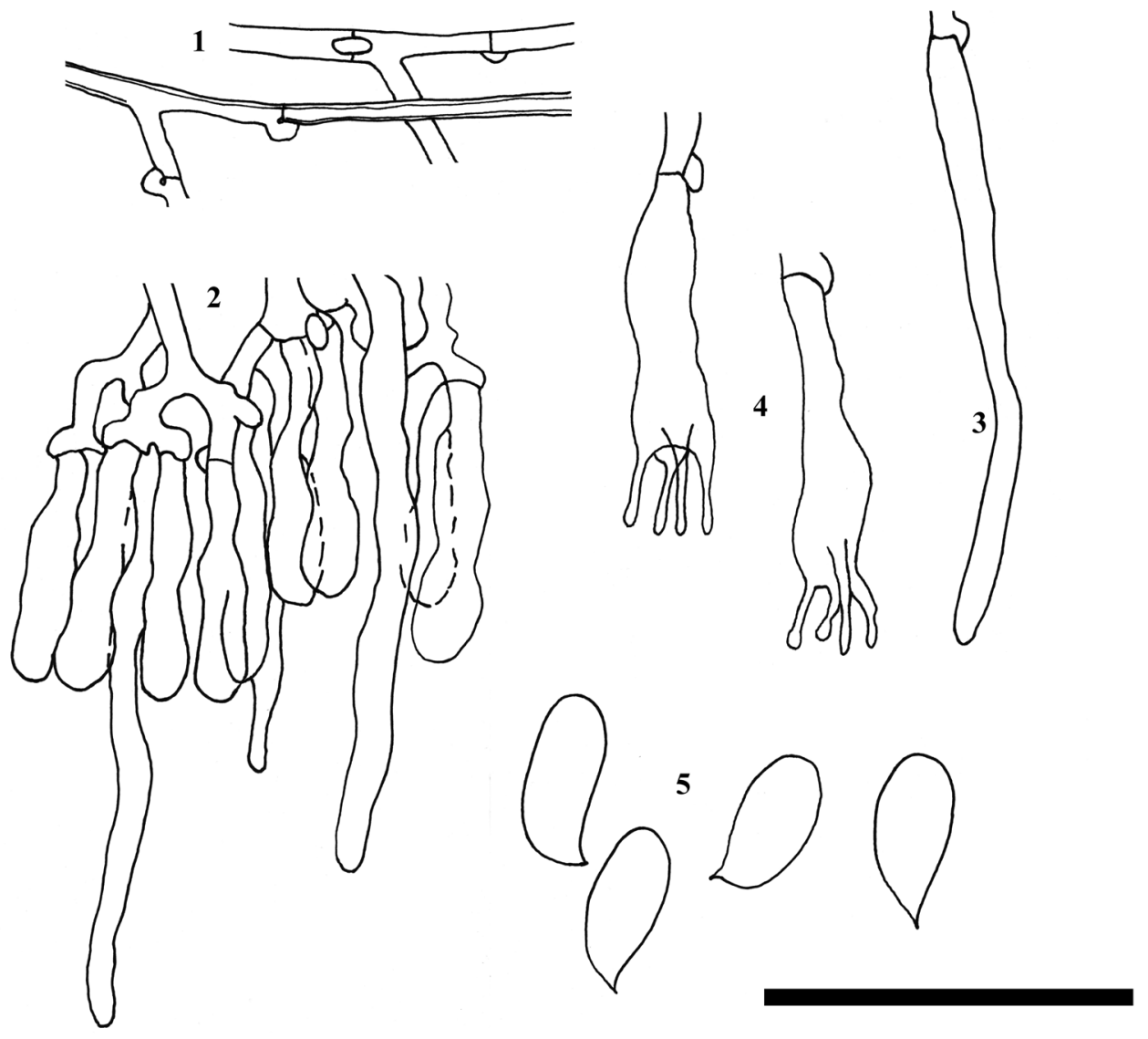

Fig. 2. Leptosporomyces mundus (INEP 1638): 1 - hyphae; 2 - hymenial elements; 3 - leptocystidia; 4 - basidia; 5 - spores. Scale bar: $20 \mu \mathrm{m}$ for $1-4,10 \mu \mathrm{m}$ for 5 .

Finland, Norway, Sweden, Ukraine, also to USA and Canada, it occurs on the wood of coniferous trees (Zmitrovich, 2008; Kunttu et al., 2016). The microscopical features of this taxon are clear and the fungus is easy to identify. However, L. mundus is rare and rarely collected species.

In Norway, it is included in the Red List with the category EN (Anonymous, 2015). This species requires a special attention and study of its distribution in the Murmansk Region.

\section{ACKNOWLEDGEMENTS}

We thank Dr. E. Borovichev and Dr. K. Pärtel for valuable comments and suggestions as well as Dr. N. Koroleva for improving the English of the manuscript. The study was carried out within the framework of the institutional research project (no. 9-13-2104) of the Institute of the Industrial Ecology Problems of the North of the Kola Science Center of RAS and the institutional research project (no. 01201255602) of the Komarov Botanical Institute of RAS and was partially supported by the Russian Foundation of Basic Researches (grants no. 15-29-02662).

\section{REFERENCES}

Ahti, T., Hämet-Ahti, L. \& Jalas J. 1968. Vegetation zones and their sections in northwestern Europe. Annales Botanici Fennici 5(3): 169-211.

Anonymous 2015. Norwegian Red List of Species. http://www.artsdatabanken.no/Rodliste

Bernicchia, A. \& Gorjón, S. P. 2010. Corticiaceae s.1. - Fungi Europaei 12: 1-1008. 
Borovichev, E. A. \&. Boychuk, M. A. 2016. Checklist of liverworts of the Pasvik State Nature Reserve (Murmansk Region, Russia). Folia Cryptogamica Estonica 53: 1-8. https://doi.org/10.12697/ fce.2016.53.01

Khimich, Y. R., Zmitrovich, I. V., Ruokolainen, A. V. 2015. Aphyllophoroid fungi of the "Pasvik" State nature Reserve (Murmansk Region). Mycology and Phytopatology 49(4): 234-241. (In Russian, with a summary in English).

Kunttu, P., Kulji, M. \& Kotiranta, H. 2016. Athelia singularis and Leptosporomyces mundus (Basidiomycota) new to Finland. Mycobiota 6: 29-37. https://doi.org/10.12664/mycobiota.2016.06.03
Moshnikov, S. A. \& Krutov, V. I. 2010. To assess the state of forests in the "Pasvik" State Nature Reserve. In: Proceedings of the III All-Russian Scientific conference with International Participation "Ecological problems of the northern regions and ways to solve them". Apatity: KRC RAS. P. 116119. (In Russian)

Parmasto, E. 1968. Conspectus systematis Corticiacearum. Tartu. 261 p.

Zmitrovich, I. V. 2008. Definitorium fungorum Rossiae. Ordo Aphyllophorales. Fasc. 3. Familia Atheliaceae et Amylocorticiaceae. Saint Petersburg: KMK. 278 p. (In Russian) 